\title{
The Australian National Maritime Museum's view from the ship and view from the shore
}

\author{
Freya Smail
}

University of Technology Sydney, Faculty of Arts and Social Sciences, PO Box 123, Ultimo

NSW 2007, Australia. freya.1.smail@student.uts.edu.au

Next year, the Australian National Maritime Museum's replica of Captain Cook's ship, HMS Endeavour, will circumnavigate Australia to commemorate 250 years of Cook landing on Australian shores. I was excited to visit the museum to hear their rationale behind this something that I have heard very mixed responses to, and which I myself thought sounded inconsiderate (and ignorant) of Australia's Indigenous history prior to my visit.

We met with Kevin Sumption, the Director of the Maritime Museum. He spoke to us about the museum's upcoming program, Encounters 2020, which encompasses Endeavour 2's impending journey. However, Kevin explained that unlike previous commemorations of Cook's arrival in Australia, the Maritime Museum will now be exploring stories of the encounter from Indigenous communities too; the view from the shore to the ship, as well as from the ship to the shore.

From where we stood on the second floor, we could see out onto the harbour. We couldn't see Endeavour's replica - she was away for cleaning - but we could see many other boats. This seemed fitting; shifting our focus from Cook's voyage to see all the others. 


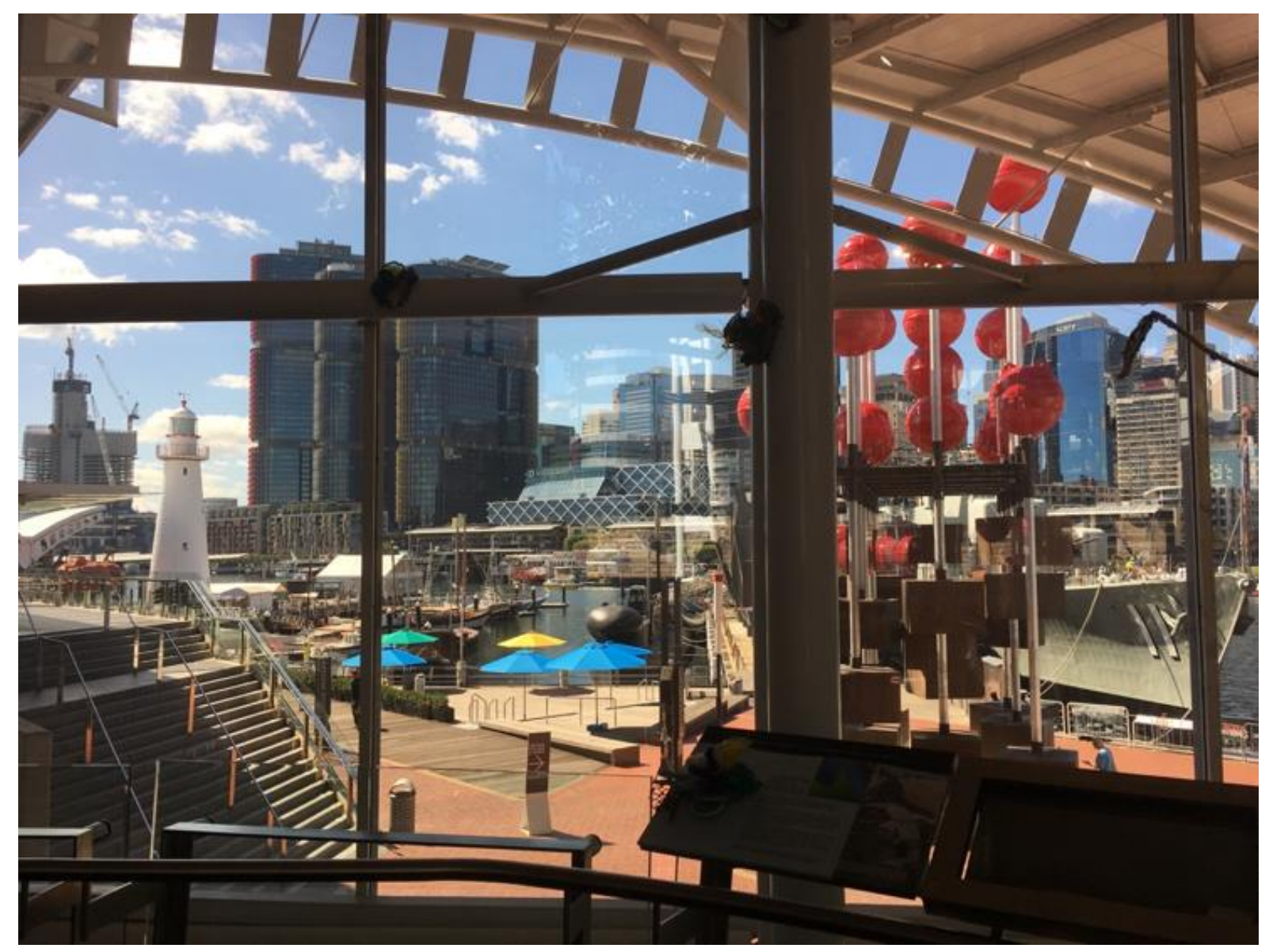

Kevin said that although the replica of Endeavour is symbolic of wrongful possession and dispossession, the museum is hoping to turn it into a point of constructive discussion and debate. I strongly agree with him that in telling the truth about our history, it is important to acknowledge what HMS Endeavour meant, and what it did, to Australia's Indigenous communities.

This site visit encouraged me to think about contemporary museums examining their objects through a lens of colonisation and invasion. I recently visited the Rijksmuseum in Amsterdam, which has signs throughout acknowledging that many of the artefacts it has on display were stolen, without permission, from their countries of origin. I admired this acknowledgement of their problematic history - they weren't pretending it didn't happen. It is an acknowledgement that I do not see enough of in Australia, but I am optimistic that the Maritime Museum's example will help make way for a new, more truthful era of historytelling.

Helen Anu, a First Nations Curator at the museum, shared with us the Au Karem Ira Lamar $L u$ exhibition, the 'Ghost Nets of the Ocean'. The nets were something harmful, damaging to the oceans and the lifeforms that live off them, that have been made into something beautiful by Indigenous and non-Indigenous Australians. I hope the museum will help Endeavour 2's 2020 voyage to do the same. 


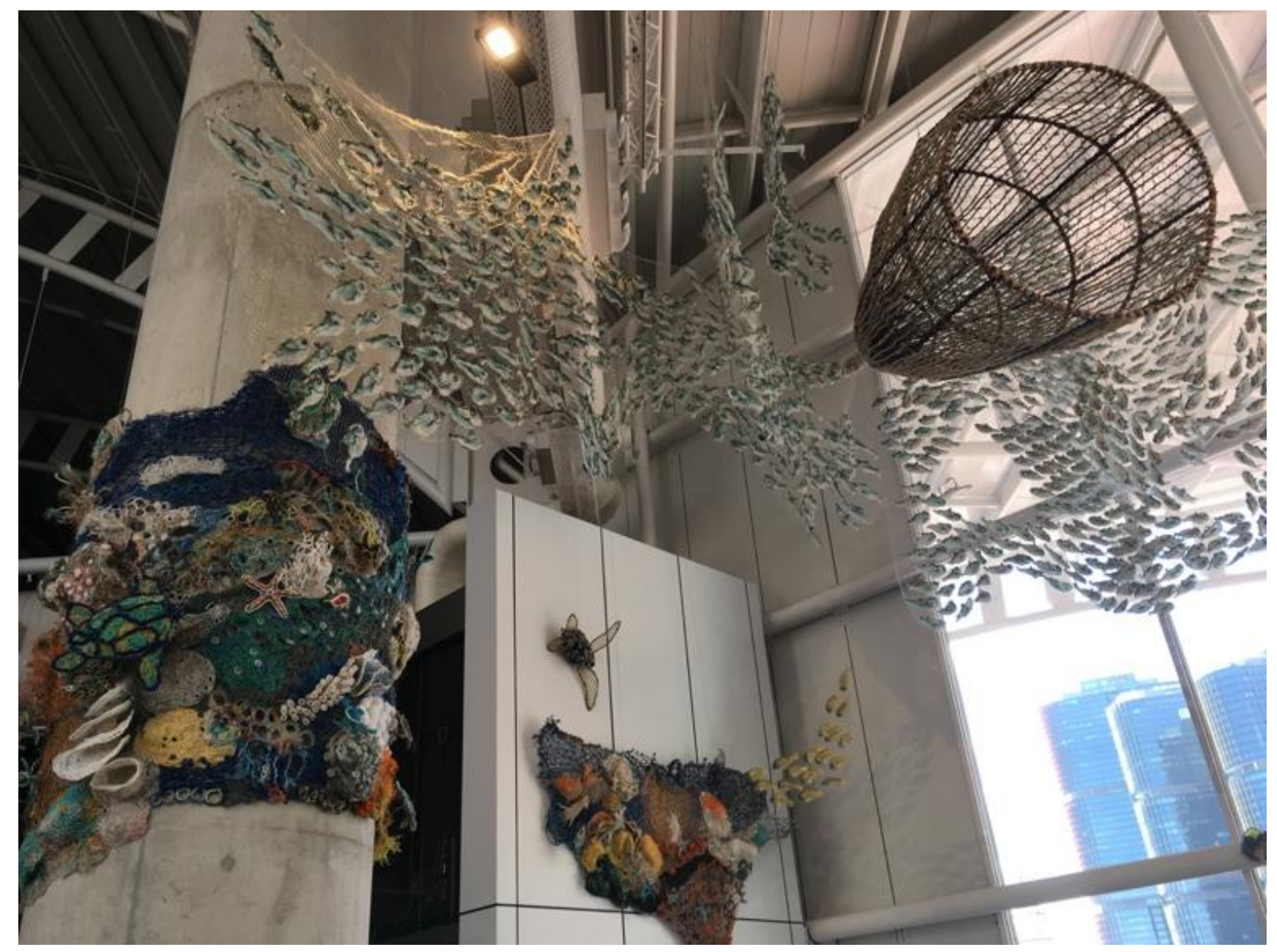

\section{References}

Australian National Maritime Museum, 2019, Au Karem Ira Lamar Lu - Ghost Nets of the Ocean, 28 March 2019, <https://www.sea.museum/whats-on/exhibitions/ghost-nets-of-theocean>. 